\title{
Identification of alternate dwarfing gene sources to widely used Dee-Gee- Woo-Gen allele of sd1 gene by molecular and biochemical assays in rice (Oryza sativa L.)
}

\author{
Chiruvuri Naga Neeraja \\ Crop Improvement Division \\ Directorate of Rice Research \\ Rajendranagar, Hyderabad-500076,AP, India
Lakshminarayana Reddy Vemireddy
Biotechnology Unit, ARI, Acharya N.G.
Ranga Agricultural University,
Rajendranagar, Hyderabad-500030, AP, India \\ Suarapaneni Malathi \\ Biotechnology Unit, ARI, Acharya N.G. \\ Ranga Agricultural University, \\ Rajendranagar, Hyderabad-500030, AP, India \\ Ebrahimali Abubacker Siddiq* \\ Biotechnology Unit, ARI, Acharya N.G. \\ Ranga Agricultural University, \\ Rajendranagar, Hyderabad-500030, AP, India \\ E-mail: easiddiq@rediffmail.com
}

Keywords: Dee-Gee-Woo-Gen, dwarfing gene, gibberellic acid assay, molecular marker, rice, sd1 gene.

Abbreviations: DGWG: Dee-Gee-Woo-Gen
GA: gibberellic acid
PCR: polymerase chain reaction
sd1: semi dwarf-1

After the success of IR8 and TN1, breeders depended heavily on these two rice cultivars for source of short stature led to the narrow genetic base to majority of present day rice varieties, as far as $s d 1$ (semi-dwarf1) gene is concerned. In addition, analysis of genetic lineage of the majority of the cultivated rice varieties in tropical Asia reveals that sd1 from DGWG (Dee-GeeWoo-Gen) is the source of dwarfing gene. Such high amount of genetic homogeneity renders rice plants vulnerable to epidemic of diseases and insect pests. In the current study, we made an attempt to identify the alternate sources of DGWG allele of sd1 gene by characterizing 29 induced and 3 spontaneous dwarf accessions employing marker for DGWG allele of $s d 1$ gene and exogenous application of gibberellic acid $\left(G_{3}\right)$. When occurrence of DGWG allele of sd1 gene and $\mathrm{GA}_{3}$ response were analyzed together, existence of two kinds of dwarfs was noticed viz., dwarf accessions with DGWG allele and dwarf accessions without DGWG allele of $s d 1$ allele exhibiting varying responses to $\mathrm{GA}_{3}$. As many as 22 of 32 dwarf accessions showed absence of DGWG allele of sd1 gene with varying response to $\mathrm{GA}_{3}$ could be used as excellent alternate sources for DGWG allele of sd1 gene. These dwarf accessions could be used for broadening the genetic base for the plant height and thereby minimize the risk of genetic vulnerability. Our strategy of combining molecular and biochemical assays can be efficiently used for identifying alternate dwarfing gene sources to the Green Revolution gene sd1.

Rice is the staple food for more than one half of the world's population. Tropical Asia accounting for over 90\% of production and consumption of rice has been growing tall statured lodging prone varieties of very low yields until the advent of the non lodging high yielding semi-dwarf varieties in sixties. The short statured varieties developed using Dee-Gee-Woo-Gen (DGWG), a dwarf of spontaneous origin, have enabled many countries in the region to achieve self-sufficiency in rice in a short span of 15 years (Sasaki et al. 2002; Spielmeyer et al. 2002). Initial attempts to study the genetics of semi-dwarfism using crosses of traditional talls with semi-dwarf varieties indicated that it was controlled by a single recessive gene

*Corresponding author 


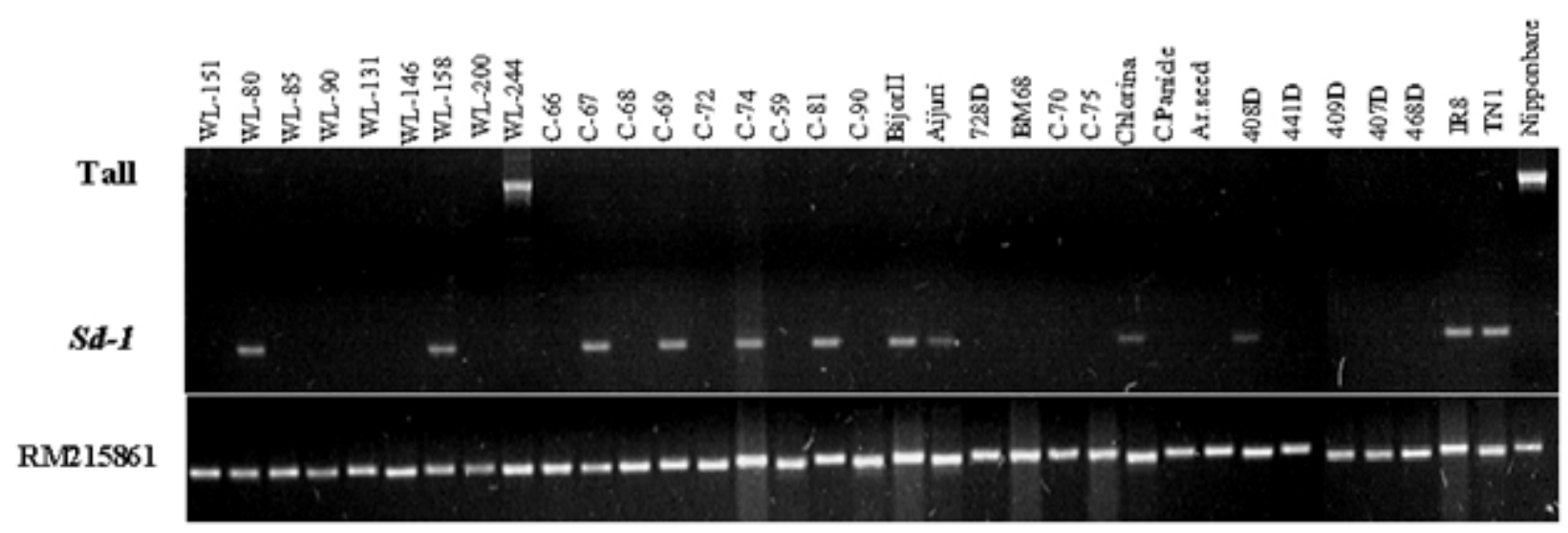

Figure 1. Characterization of dwarf accessions at sd1 locus. A 731bp product is there in all tall rice cultivars. 348bp product is there in all accessions with DGWG allele of sd1 RM215861 marker was used as positive control for DNA amplification of all rice accessions.

designated as sd1 (Singh et al. 1979; Cho et al. 1994). The sd1 gene has been reported to reduce plant height by $25 \%$ through approximately proportional reductions in lengths of the top five internodes; with practically no effect on panicle length (Rutger, 1984). Later, three research groups have mapped sd1 gene independently to chromosome 1 and shown to encode a $\mathrm{GA}_{20}$ oxidase (GA20ox) (Monna et al. 2002; Sasaki et al. 2002; Spielmeyer et al. 2002), an enzyme that catalyzes the conversion of $\mathrm{GA}_{53}$ to $\mathrm{GA}_{20}$ in gibberellic acid (GA) biosynthesis. Semi-dwarf rice cultivars possessing the sd1 allele from DGWG are characterized by a 383bp deletion in the GA20ox gene that introduces a stop codon resulting in a highly truncated and inactive enzyme. Thus the normal height of the semi-dwarf rice is restored by exogenous application of GA (Ellis and Spielmeyer, 2002; Sasaki et al. 2002; Spielmeyer et al. 2002).

The success of DGWG gene based varieties such as IR8 and Taichung (Native) 1 has made breeders allover to depend excessively on these two rice cultivars for source of short stature. With over $90 \%$ of the high yielding varieties in cultivation today having DGWG gene (Kikuchi and Ikehashi, 1984; Cho et al. 1994; Spielmeyer et al. 2002), the genetic base, as result is quite narrow, as far as $s d 1$ gene is concerned. Apprehending that genetic homogeneity to that high extent might render a vital character like plant type genetically vulnerable to sudden outbreak of diseases and insect pests, many efforts have been made since last two or three decades for broadening the genetic base through identification and use of alternate sources of dwarfing gene (Reddy and Padma, 1976; Singh et al. 1979). Genetic analysis of a large number of dwarfs of spontaneous and induced origin has revealed occurrence of dwarfs non-allelic to $s d 1$ appears to be rare. Past efforts to identify dwarfing gene sources alternate to $s d 1$ gene by conventional allelic relationships failed to yield desired results on account of difficulties experienced in phenotyping the segregating population and hybrid sterility in cross between dwarfs of indica and japonica origin.

In rice, as many as 61 dwarfing genes designated as $d 1$ to $d 61$ have been identified (Cho et al. 1994; Ashikari and Matsuoka, 2002). Even though many different dwarf accessions of mutant and spontaneous origin have been tried as alternate sources for developing semi-dwarf varieties, none other than sd1 locus of DGWG source proved to be of practical value. Different alleles of this locus have been used by scientists of Asia and America (Asano et al. 2007). Several of the dwarf mutants accumulated over a period have been characterized at molecular level and their dwarfness has been a attributed to defective signal transduction molecules like heterotrimericG protein (Ueguchi-Tanaka et al. 2000), homeobox like OSH15 (Sato et al. 1999), brassinosteriods (Yamamuro et al. 2000) and various GA biosynthesis genes (Sasaki et al. 2002; Itoh et al. 2004). Realizing the importance of broadening the genetic base for plant height, the present study was initiated to identify alternative dwarfing gene source(s) among a collection of induced and spontaneous mutants using molecular markers linked to sd1 locus that can distinguish DGWG allele type from the other alleles and exogenous application of GA.

\section{MATERIALS AND METHODS}

Details of 34 rice genotypes comprising 29 induced and 3 spontaneous dwarf accessions, and two DGWG based semidwarf cultivars viz., TN1 and IR8 and screened to identify alternate sources to $s d 1$ are summarized in Table 1. One tall variety (Nipponbare) was included as a check for PCR amplification of sd1 allele.

\section{DNA extraction}

DNA of the experimental material was isolated following the modified potassium acetate method (Dellaporta et al. 1983). 


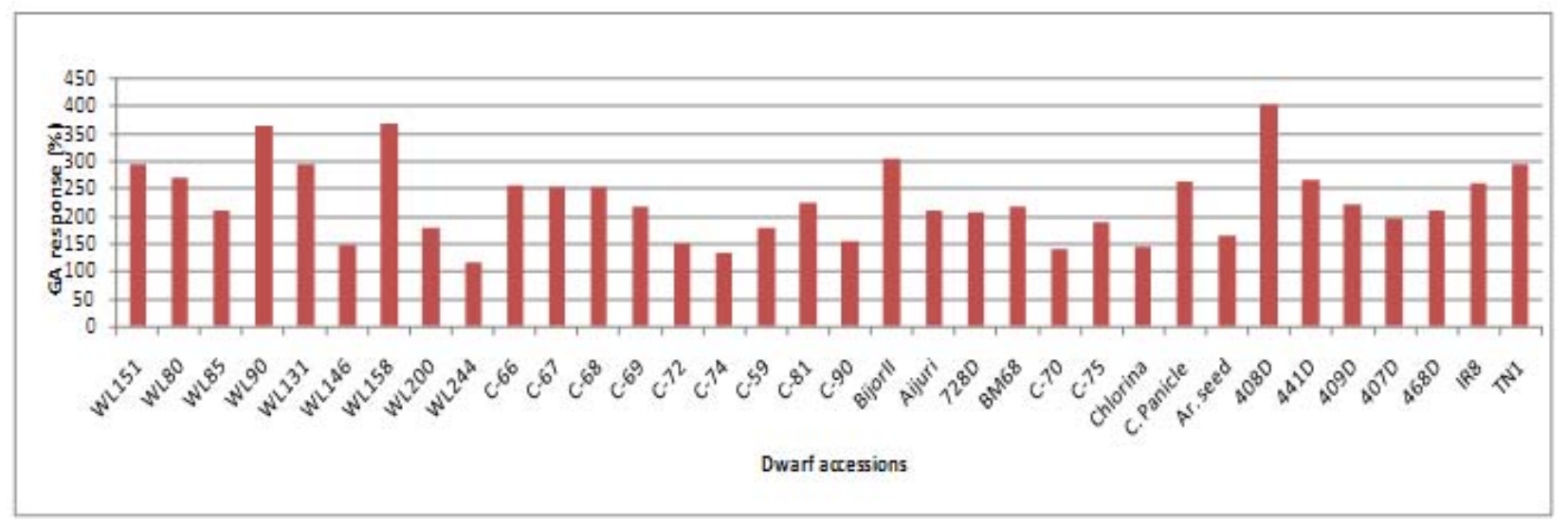

Figure 2. Characterization of dwarf accessions using GA responsiveness. GA response $=(G A$ response in dwarf/ GA response in control)*100.

\section{Detection of $s d 1$ allele}

Based on the 383bp deletion in sd1 allele of DGWG, reported PCR primers were used for detection of sd1 allele (Ellis and Spielmeyer, 2002). Sd1- F: 5'- CAC GCA CGG GTT CTT CCA GGT G -3'. Sd1- R: 5’- AGG AGA ATA GGA GAT GGT TTA CC- 3’.

Amplification of DNA was performed in $10 \mathrm{mM}$ Tris- $\mathrm{HCl}$ $\mathrm{pH}$ 9.0, $50 \mathrm{mM} \mathrm{KCl}, 1.5 \mathrm{mM} \mathrm{MgCl}_{2}, 0.2 \mathrm{mM}$ dNTPs, $1 \mathrm{U}$ of Taq DNA polymerase (Bangalore Genei, India) and 30 ng of DNA per 20-ml reaction using a GeneAmp PCR system 9700 (PE Applied Biosystems, USA). After initial denaturation for $5 \mathrm{~min}$ at $94^{\circ} \mathrm{C}$, five cycles at each cycle comprised $30 \mathrm{sec}$ denaturation at $94^{\circ} \mathrm{C}, 30 \mathrm{sec}$ annealing at $55^{\circ} \mathrm{C}, 1 \mathrm{~min}$ and $30 \mathrm{sec}$ extension at $72^{\circ} \mathrm{C}, 30$ cycles at each cycle comprised $20 \mathrm{sec}$ denaturation at $94^{\circ} \mathrm{C}$, $20 \mathrm{sec}$ annealing at $55^{\circ} \mathrm{C}, 1 \mathrm{~min}$ extension at $72^{\circ} \mathrm{C}$ with a final extension for $10 \mathrm{~min}$ at $72^{\circ} \mathrm{C}$. Amplified products were mixed with bromophenol blue (gel loading dye) and were electrophoresed on a $2 \%$ agarose gel using $1 \mathrm{x}$ Tris Borate buffer $\mathrm{pH}$ 8.0. The gels were stained in ethidium bromide and were documented using Alpha Imager 1220 (Alpha Innotech, USA).

\section{Gibberellic acid $\left(\mathrm{GA}_{3}\right)$ treatment}

Seeds of the experimental material were surface sterilized with $2.0 \% \mathrm{HgCl}_{2}$ solution for $30 \mathrm{~min}$ and then washed with water. They were placed in petri dishes lined with wet filter paper and then kept in dark at $30^{\circ} \mathrm{C}$ for two days for germination. Elongation of shoot was quantified by microdrop method (Mitsunaga et al. 1994). Ten uniformly germinated seeds were placed on a $1 \%$ agar plate-five for gibberellic acid treatment and five as controls and allowed to grow at $25^{\circ} \mathrm{C}$ under fluorescent light till emergence of second leaf sheath. After two days, $1 \mu$ l of a solution of $\mathrm{GA}_{3}(10 \mathrm{mg} / \mathrm{ml})$ in ethanol was applied to coleoptile of rice seedlings. Three days after this treatment, the length of the second-leaf sheath was measured and average of 5 plants was taken to calculate $\mathrm{GA}_{3}$ response (GAR) as under: $\mathrm{GAR}=\left(\mathrm{GA}_{3}\right.$ treatment/control $) * 100$.

\section{Plant growth conditions}

The genomic DNA was analyzed using RAPDs molecular markers (Williams et al. 1990; Schnell et al. 1995). We standardized the DNA amplification conditions by assessing the following: DNA concentration, primer concentration; different brands, concentrations and storage time of the Taq polymerase, as well as temperatures for PCR amplification $25 \mu$ l-reactions of PCR contained: 25 ng of DNA, $0.25 \mathrm{mM}$ of dCTP, dGTP, dATP and dTTP respectively; $2.5 \mathrm{mM}$ of $\mathrm{MgCl}, 1 \mathrm{U}$ of Taq polymerase Invitrogen ${ }^{\circledR}$ and Promega ${ }^{\circledR}$ and $7 \mu \mathrm{M}$ of primer. Thermocycler (Biorad MyCycler ${ }^{\circledR}$ ) was programmed for 34 cycles, with a denaturating step of $30 \mathrm{sec}, 94^{\circ} \mathrm{C}$, an annealing temperature of $40^{\circ} \mathrm{C}$ for $30 \mathrm{sec}$, and an extension step at $72^{\circ} \mathrm{C}$ for $1 \mathrm{~min}$.

Sixty Operon ${ }^{\circledR}$ RAPD’s primers were evaluated: Kit A (120), Kit B (1-20), OPAA6, OPAB11, OPAB14, OPAC4, OPAC7, OPAC10, OPAD1, OPAD4, OPAD10, OPAD14, OPAG6, OPAG8, OPAH5, OPAH10, OPAM4, OPAM10, OPAM13, OPAN5, OPAN8 and OPAN17. Two individuals from each department were taken to select the primers that generated a good polymorphism level. A negative control and two positive controls were included (Curatella americana and a rice variety). From the 60 primers that were evaluated in the six populations, 10 did not amplify, 18 produced a low amplification, 11 primers were monomorphic, and 16 were polymorphic. Five (5) primers were selected from the 16 primers that were polymorphic (Table 1) and were therefore launched in the populations. The amplification products were run in 1.5\% agarose gels prepared in TBE $1 \mathrm{X}$, stained with ethidium bromide [0.5 
Table 1. Details of the dwarf accessions included in the study

\begin{tabular}{|c|c|c|c|}
\hline S.No. & Name of the accessions & Source of the accessions & Nature of the accession \\
\hline 1 & Cigar Panicle (CRRI No. 35833) & Central Rice Research Institute (CRRI), Cuttack & Induced (Gamma rays) \\
\hline 2 & Ratna Chlorina (CRRI No. 35835) & Central Rice Research Institute (CRRI), Cuttack & Induced (Gamma rays) \\
\hline 3 & BM 68 (IC-144565) & Indian Agricultural Research Institute (IARI), New Delhi & Induced (Gamma rays) \\
\hline 4 & WL 51 & Bhabha Atomic Research Centre (BARC), Mumbai & Induced (Gamma rays) \\
\hline 5 & WL 80 & Bhabha Atomic Research Centre (BARC), Mumbai & Induced (Gamma rays) \\
\hline 6 & WL 85 & Bhabha Atomic Research Centre (BARC), Mumbai & Induced (Gamma rays) \\
\hline 7 & WL 90 & Bhabha Atomic Research Centre (BARC), Mumbai & Induced (Gamma rays) \\
\hline 8 & WL 131 & Bhabha Atomic Research Centre (BARC), Mumbai & Induced (Gamma rays) \\
\hline 9 & WL 146 & Bhabha Atomic Research Centre (BARC), Mumbai & Induced (Gamma rays) \\
\hline 10 & WL 158 & Bhabha Atomic Research Centre (BARC), Mumbai & Induced (Gamma rays) \\
\hline 11 & WL 200 & Bhabha Atomic Research Centre (BARC), Mumbai & Induced (Gamma rays) \\
\hline 12 & WL 244 & Bhabha Atomic Research Centre (BARC), Mumbai & Induced (Gamma rays) \\
\hline 13 & C-59 & Bhabha Atomic Research Centre (BARC), Mumbai & Induced (Gamma rays) \\
\hline 14 & C-66 & Bhabha Atomic Research Centre (BARC), Mumbai & Induced (Gamma rays) \\
\hline 15 & C-67 & Bhabha Atomic Research Centre (BARC), Mumbai & Induced (Gamma rays) \\
\hline 16 & C-68 & Bhabha Atomic Research Centre (BARC), Mumbai & Induced (Gamma rays) \\
\hline 17 & C-69 & Bhabha Atomic Research Centre (BARC), Mumbai & Induced (Gamma rays) \\
\hline 18 & C-70 & Bhabha Atomic Research Centre (BARC), Mumbai & Induced (Gamma rays) \\
\hline 19 & C-72 & Bhabha Atomic Research Centre (BARC), Mumbai & Induced (Gamma rays) \\
\hline 20 & C-74 & Bhabha Atomic Research Centre (BARC), Mumbai & Induced (Gamma rays) \\
\hline 21 & C-75 & Bhabha Atomic Research Centre (BARC), Mumbai & Induced (Gamma rays) \\
\hline 22 & C-81 & Bhabha Atomic Research Centre (BARC), Mumbai & Induced (Gamma rays) \\
\hline 23 & C-90 & Bhabha Atomic Research Centre (BARC), Mumbai & Induced (Gamma rays) \\
\hline 24 & 407D & Punjab Agricultural University (PAU), Ludhiana & Induced (Gamma rays) \\
\hline 25 & 408D (BSDM ACC3019 SC459) & Punjab Agricultural University (PAU), Ludhiana & Induced (Gamma rays) \\
\hline 26 & 409D & Punjab Agricultural University (PAU), Ludhiana & Induced (Gamma rays) \\
\hline 27 & 441(DM24 ACC3251 SC165-B) & Punjab Agricultural University (PAU), Ludhiana & Induced (Gamma rays) \\
\hline 28 & $468 \mathrm{D}$ & Punjab Agricultural University (PAU), Ludhiana & Induced (Gamma rays) \\
\hline 29 & $728 \mathrm{D}$ & Punjab Agricultural University (PAU), Ludhiana & Induced (Gamma rays) \\
\hline 30 & Bijor II & Assam Agricultural University (AAU), Titabar & Spontaneous \\
\hline 31 & Aijuri & Assam Agricultural University (AAU), Titabar & Spontaneous \\
\hline 32 & Area old seed & Assam Agricultural University (AAU), Titabar & Spontaneous \\
\hline 33 & IR8 & Directorate of Rice Research, Hyderabad & Semi-dwarf \\
\hline 34 & TN1 & Directorate of Rice Research, Hyderabad & Semi-dwarf \\
\hline
\end{tabular}


$\mu \mathrm{g} / \mathrm{ml}$ and a voltage of $4-5 \mathrm{~V} / \mathrm{cm}$ was applied to the electrophoretic horizontal camera (Gibco ${ }^{\circledR}$ Horizon 20-25) for 2 hrs. Subsequently, the amplified products were visualized and photographed with the Gel Doc XR System (BioRad®).

\section{Observation on the number of internodes, length of internodes and plant height}

Number of internodes and length of each of the internodes were recorded for at least five plants. Plant height was measured by actual measurement $(\mathrm{cm})$ from soil surface to tip of the tallest panicle (awns excluded) from at least five plants.

\section{RESULTS}

In the present study, phenotypic data of 32 dwarf accessions and two semi-dwarf varieties were collected.

\section{Phenotypic characterization of the dwarf accessions}

Number of internodes ranged from 2 to 4 . Unlike the typical semi-dwarf varieties (4), most of the dwarf accessions (20) included in the study has 3 internodes
(Figure 3A and Supplementary Figure 1). Two dwarf accessions viz., C-74 and C-81 have two internodes whereas remaining all (10) having four internodes like semi-dwarf rice varieties. Length of the first (top most internode in the plant) internode was found to account for more than $60 \%$ of the plant height in the accessions WL200, C-74, 408D and 468D (genotypes with two internodes were not considered). Only in two genotypes viz., WL90 and C-70 length of the second internode was more than the first internode. Length of the third and fourth internodes was highly variable ranging from 3.4 to $25.6 \%$ and 2 to $10 \%$, respectively (Figure 3A). Plant height of the 32 dwarf accessions ranged from $30 \mathrm{~cm}$ to $96 \mathrm{~cm}$. The height of the genotypes with four and three internodes ranged from $42 \mathrm{~cm}$ to $89 \mathrm{~cm}$ and $30 \mathrm{~cm}$ to $96 \mathrm{~cm}$ respectively. The height of the genotypes with two internodes ranged from $33 \mathrm{~cm}$ and $44 \mathrm{~cm}$ (Figure 3B).

In the present study, 32 dwarf accessions have screened for presence of DGWG allele of sd1 gene and GA response (Table 1). The dwarf accessions exhibited both DGWG allele of sd1 gene and moderate response to GA treatment were considered to be allelic to sd1 gene from DGWG and those behaving otherwise as alternates to DGWG allele of sd1 gene.

(a)

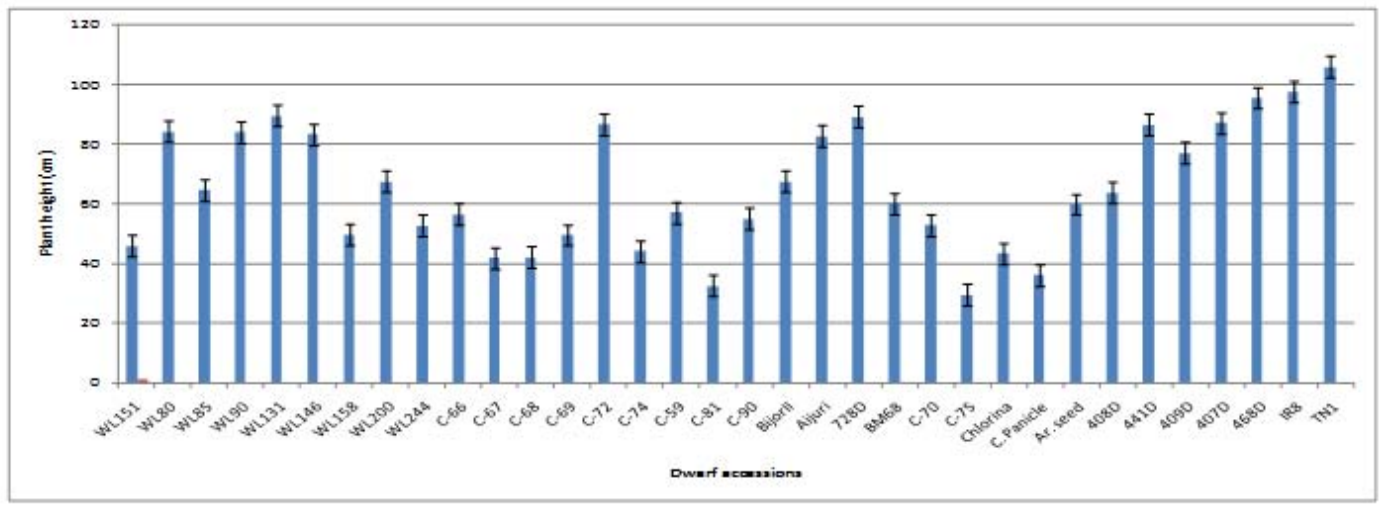

(b)

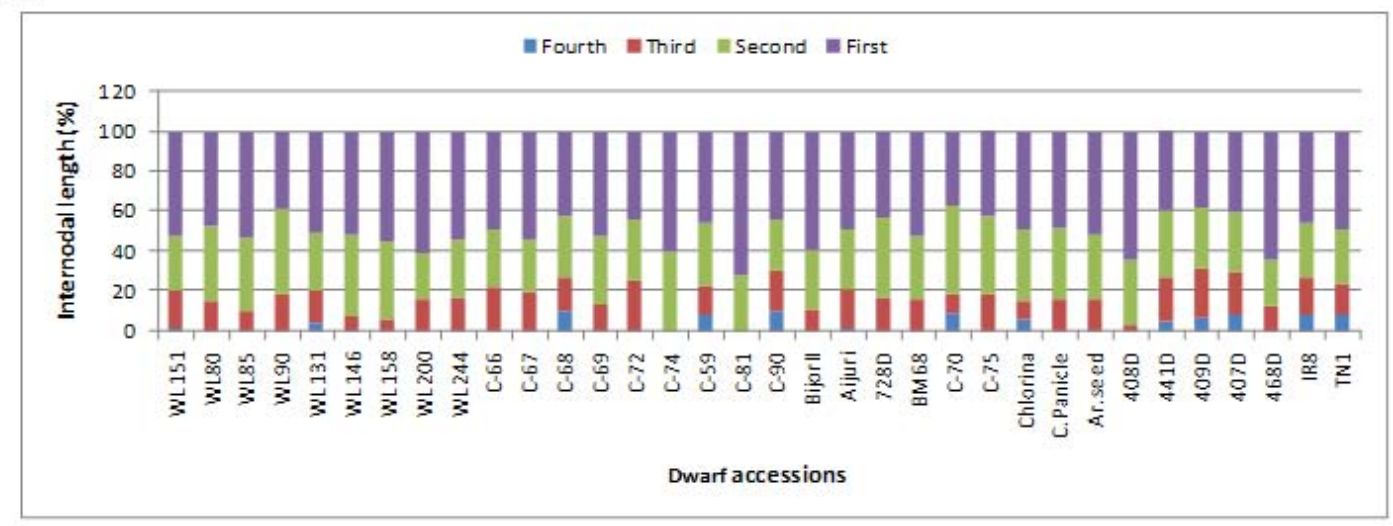

Figure 3. Characterization od dwarf accession using intermodal length (a) and plant height (b). 
Table 2. Classification of dwarf accessions based on DGWG allele of sd1 gene and $G A_{3}$ response

\begin{tabular}{|c|c|c|}
\hline GA $_{3}$ response & Dwarfing gene & Accessions \\
\hline Medium & sd1 & WL80, C-67, C-69, C-81, Aijuri \\
\hline High & sd1 & WL158, Bijorll, 408D \\
\hline Low & sd1 & C-74, Chlorina \\
\hline Medium & asd1 & WL151, WL85, WL131, C-66, C-68, 728D, MB68, C-75, \\
C.Panicle, 441D, 409D, 407D and 468D
\end{tabular}

asd1: alternate semi-dwarfing gene

\section{Characterization of dwarf accessions at sd1 locus}

Based on the presence of DGWG allele of sd1 gene (348bp PCR product), 10 dwarf accessions viz., WL80, C-67, C-69, C-81, Aijuri, WL158, BijorII, 408D, C-74, and Chlorina were identified to be allelic to DGWG allele of sd1 gene and the rest as non-DGWG allele type of sd1 gene (Figure 1).

\section{Characterization of "null alleles" in dwarf accessions at sd1 locus}

To characterize the "null allele" in 21 accessions that did not give any PCR product at the sd1 locus, we have used seven rice microsatellites (www.gramene.org) in upstream and two in downstream region of the sd1 gene with an average distance between markers is approximately $125 \mathrm{~kb}$ (Supplementary Table 1). Although all induced dwarf accessions are treated with same mutagen i.e, gamma rays we have noticed different lengths of the sequence deletion around the sd1 gene. Of 32 dwarf accessions, it is surprising to note that, as many as 18 dwarf accessions showed the expansion of the deletion around the sd1 gene ranging from $59.82 \mathrm{~kb}$ to $783.11 \mathrm{~kb}$ (including the $s d 1$ gene region). In some dwarf accessions viz., WL190, C-68 and 409D, the deletion is restricted to sd1 gene only. In remaining dwarf accessions deletion is restricted to DGWG allele of sd1 gene (383bp deletion) except WL244 in which full length $s d 1$ gene is present. Either length of the expansion or presence or absence of the DGWG allele of the $s d 1$ not matching to the response of the GA treatment. For instance, C-59 and 469D the length of the deletion is $192.56 \mathrm{~kb}$ but their response to GA treatment is low and medium respectively.

\section{DISCUSSION}

Apprehending the genetic vulnerability of the present day semi-dwarf rice cultivars on account of their having one and the same dwarfing gene (sd1) for plant height (Cho et al. 1994; Spielmeyer et al. 2002) and keeping in view the need for alternate dwarfing gene sources of still higher physiological efficiency, the present attempt was made to identify alternate sources to DGWG allele of $s d 1$ by characterizing of 29 induced (gamma rays) and 3 spontaneous dwarf accessions at physiological and molecular levels. Molecular assay was done using precise marker available for identifying DGWG allele of $s d 1$ gene while physiological assay by sensitiveness to exogenously applied $\mathrm{GA}_{3}$. Generally, rice varieties with DGWG allele of sd1 gene reportedly exhibit moderate response to exogenously applied $\mathrm{GA}_{3}$ (Kumar and Singh, 1984; Hedden, 2003). When specific amplification of sd1 allele and $\mathrm{GA}_{3}$ response were analyzed together, existence of two kinds of dwarfs were noticed viz., dwarfs having sd1 allele and those characterized by absence of sd1 allele but with varying responses to $\mathrm{GA}_{3}$. Presence of DGWG allele of $s d 1$ allele in the genotypes irrespective of their $\mathrm{GA}_{3}$ response as observed in the present study suggest involvement of various other GA biosynthesis related gene(s) in determining plant height. Mapping analysis of four GA 20ox-like genes viz., OsGA20ox1, OsGA20ox2, OsGA20ox3 and OsGA20ox4 reveal them to be located on chromosomes 3, 1, 7 and 5 respectively and OsGA20ox2 is identical to the rice green revolution gene $s d 1$ (Sakamoto et al. 2004). OsGA20ox1 encoding an isoform of gibberellin 20-oxidase has been found to regulate of plant stature in rice (Oikawa et al. 2004). Other than GA 20 oxidase genes, ent-kaurene oxidase (KO) has been found to be implicated in determining semi-dwarf nature of Tan-Ginbozu (d35) 
(Itoh et al. 2004) and involvement of GA 3 oxidase-2 which encoded by the dwarf gene (d18) was reported to cause dwarf nature.

Though these dwarf mutants could be defective at one or the other steps in the GA biosynthetic pathway, which could be rescued by the application of GA. However, dwarfness need not always as a result of deficiency of GAlike substances but of other factors. For instance, the $d_{1}$ type dwarf was reported to be defective in $\alpha$-subunit of the heterotrimeric G protein affects gibberellin signal transduction (Ashikari et al. 1999; Ueguchi-Tanaka et al. 2000). Likewise, loss of function mutation in the rice homeobox gene OSH15 was also reported to affect the architecture of internodes resulting in $d 6$ dwarf plants (Sato et al. 1999). Characterization of dwarfs of $d 61$ mutants reveals a protein kinase with high similarity to a putative brassinosteroid receptor in Arabidopsis to be linked to prevention of internode elongation (Yamamuro et al. 2000). A brassinosteroid-deficient mutant, ebisu dwarf $d_{2}$ has been reported to be caused by loss of function of a new member of cytochrome P450 (Hong et al. 2002).

Difference in plant height in general between tall and semidwarf types in particular is mainly due to differences in the length of the first (subtending panicle) and the second (subtending flag leaf/stem) internodes (Harada and Vergara, 1972). In the present study, internodal length has been found to vary with genotypes. Some genotypes like WL131, C-68, C-59, C-70 and Aijuri are characterized by the noticeably shortened lower internodes without significant reduction in the length of panicle. Such plant types among the dwarfs studied might be value as potential genetic resources for evolving non lodging ideotypes of high productivity. The pattern of internodal elongation is like that of $s d 1$ but with twin advantages as of having their centre of gravity relatively at lower position thereby enabling the plant to withstand lodging and the long upper internode causing least reduction in panicle length and facilitating better panicle emergence. Though dwarf mutatnts of japonica could be classified based on the elongation pattern of upper four internodes into $d n, d m, d 6$, sh and $n l$ types (Takeda, 1977; Sato et al. 1999), the dwarf genotypes included in the present study could not be classified into such groups, as their tall parent of the genotypes (unknown for majority of them) are not included. However, the following two specific patterns were noted other than normal ratio, viz., (i) length of second internode exceeding that of the first internode in accessions like WL90, C-70 and (ii) Excessive shortening of internodes below the second internode in accessions like C-70.

Genetic dwarfing is generally associated with reduction of internode length or decrease in internode number or both (Futsuhara et al. 1967). The present finding based on a variety of dwarf accessions of both induced and spontaneous origin suggest that number of internodes was not as much associated as length of internodes with plant height.
Most of the dwarf mutants identified in rice are not used in crop improvement because they are associated with one or other undesirable traits like severe dwarfism, sterility, or abnormal plant height and grain development etc. Some of the dwarf mutants in the present study have been found to be of good phenotypes characterized by inhibition of elongation of lower internodes, least reduction of length of top two internodes and hence normal panicle size, erect foliage etc (Supplementary Figure 1). They could be useful profitably be exploited in breeding for alternate ideal plant types, if the severity of their dwarfism were controlled.

In summary, dwarfing appears to be caused by different mechanisms, as observed in the present study as well as from earlier reports (Huang et al. 1996; Sakamoto et al. 2003). The success of $s d 1$ of DGWG was attributed to right combination of the defective OsGA20ox2 to reduce plant height and expression of other GA 20-oxidase (s) including OsGA20ox1 to balance normal development or reproduction related systems (Sasaki et al. 2002). Presence of sd1 allele in genotypes differing in their level of $\mathrm{GA}_{3}$ response such as WL158, BijorII, 408D, C-74 and Chlorina found in the present study suggest involvement of various other genes that are not included in the GA biosynthesis in determining the plant height. Although the dwarf accessions belonging to this group are allelic to $s d 1$, they might be associated with modifier genes of different strengths in biosynthesis of GA. In addition, most of the accessions 22 of 32, showed absence of DGWG allele of sd1 gene with varying response to $\mathrm{GA}_{3}$. The dwarf accessions without $s d 1$ gene but with responding variedly to GA treatment could be used as excellent alternate sources for $s d 1$ gene tentatively designated as "asd1". Even though one dwarf accession i.e, WL244 produces functional protein of OsGA20ox-2, its dwarfness appears to be controlled by genes which are not involved in pathway of GA biosynthesis. When amplification of the entire sd1 gene and its surrounding region tried, many dwarfs failed to give amplified PCR products indicating the 383bp deletion (DGWG allele) of sd1 gene is expanded downstream and upstream of the sd1 gene and this expansion of sequence deletion ranging from $59.82 \mathrm{~kb}$ to $783.11 \mathrm{~kb}$. This clearly suggests that the sd1 locus is either highly mutable or it might have undergone high selection pressure since beginning of green revolution on account of the extensive continuous and excessive cultivation of sd1 gene based varieties since their advent in the mid sixties. Contrary to the generally held view, spontaneous dwarf mutants are largely allelic to sd1 of DGWG (Singh et al. 1979), in the present study, one of the spontaneous dwarf accessions i.e., Area old seed could be non-allelic to sd1. Although further experiments are required to study the mode of inheritance of the newly non-allelic dwarfing genes, our strategy of combining molecular and biochemical assays can be efficiently used for identifying new alternate dwarfing gene sources to the Green Revolution gene sd1. Use of identified new sources of semi-dwarfism along with DGWG gene in future breeding programme could help greatly broaden the 
genetic base for the plant height and thereby minimize the risk of genetic vulnerability.

\section{REFERENCES}

ASANO, K.; TAKASHI, T.; MIURA, K.; QIAN, Q.; KITANO, H.; MATSUOKA, M. and ASHIKARI, M. Genetic and molecular analysis of utility of sd1 alleles in rice breeding. Breeding science, November 2007, vol. 57, p. 53-58

ASHIKARI, M. and MATSUOKA, M. Application of rice genomics to plant biology and breeding. Botanical Bulletin of Academia Sinica, January 2002, vol. 43, no.1, p. 1-11.

ASHIKARI, M.; WU, J.; YANO, M.; SASAKI, T. and YOSHIMURA, A. Rice gibberellin-insensitive dwarf mutant gene Dwarf 1 encodes the alpha-subunit of GTPbinding protein. Proceedings of the National Academy of Sciences of the United States of America, August 1999, vol. 96, no. 18, p. 10284-10289.

CHO, Y.G.; EUN, M.Y.; MCCOUCH, S.R. and CHAE, Y.A. The semidwarf gene, sd-1, of rice (Oryza sativa L.). II. Molecular mapping and marker-assisted selection. Theoretical and Applied Genetics, September 1994, vol. 89, no. 1, p. 54-59.

DELLAPORTA, S.; WOOD, J. and HICKS, J. A. plant DNA mini preparation: version II. Plant Molecular Biology Reporter, September 1983, vol. 1, no. 4, p. 19-21.

ELLIS, M. and SPIELMEYER, W. "Perfect" markers for the rice sd-1 semidwarfing gene. International Rice Research Notes, December 2002, vol. 27, no. 2, p. 13-14.

FUTSUHARA, Y.; TORIYAMA, K. and TSUNODA, K. Breeding of new rice variety Reimei by gamma-ray irradiation. Japanese Journal of Breeding, 1967, vol. 17, no. 2, p. 85-90.

HARADA, J. and VERGARA, B.S. Growth pattern of tall and short lines of rice and their response to gibberellin. Annals of Botany, June 1972, vol. 36, no. 3, p. 571-577.

HEDDEN, P. The genes of the green revolution. Trends in Genetics, January 2003, vol. 19, no. 1, p. 5-9.

HONG, Z.; UEGUCHI-TANAKA, M.; SHIMIZU-SATO, S.; INUKAI, Y.; FUJIOKA, S.; SHIMADA, Y.; TAKATSUTO, S.; AGETSUMA, M.; YOSHIDA, S.; WATANABE, Y.; UOZU, S.; KITANO, H.; ASHIKARI, $M$. and MATSUOKA, M. Loss-of-function of a rice brassinosteroid biosynthetic enzyme, C-6 oxidase, prevents the organized arrangement and polar elongation of cells in the leaves and stem. Plant Journal, November 2002, vol. 32, no. 4, p. 495-508.

HUANG, N.; COURTOIS, B.; KHUSH, G.S.; LIN, H.; WANG, G.; WU, P. and ZHENG, K. Association of quantitative trait loci for plant height with major dwarfing genes in rice. Heredity, 1996, vol. 77, no. 2, p. 130-137.

ITOH, H.; TATSUMI, T.; SAKAMOTO, T.; OTOMO, K.; TOYOMASU, T.; KITANO, H.; ASHIKARI, M.; ICHIHARA, S. and MATSUOKA, M. A rice semi-dwarf gene, Tan-Ginbozu D35, encodes the gibberellin biosynthesis enzyme, ent-kaurene oxidase. Plant Molecular Biology, July 2004, vol. 54, no. 4, p. 533-547.

KIKUCHI, F. and IKEHASHI, H. Semidwarfing genes of high-yielding rice varieties in Japan. Rice Genetics Newsletter, November 1984, vol. 1, p. 93-94.

KUMAR, I. and SINGH, T. A rapid method for identifying different dwarfing genes in rice. Rice Genetics Newsletter, November 1984, vol. 1, p. 134-135.

MITSUNAGA, S.; TASHIRO, T. and YAMAGUCHI, J. Identification and characterization of gibberellin-insensitive mutants selected from among dwarf mutants of rice. Theoretical and Applied Genetics, January 1994, vol. 87, no. 6, p. 705-712.

MONNA, L.; KITAZAWA, N.; YOSHINO, R.; SUZUKI, J.; MASUDA, H.; MAEHARA, Y.; TANJI, M.; SATO, M.; NASU, S. and MINOBE, Y. Positional cloning of rice semidwarfing gene, sd-1: rice "green revolution gene" encodes a mutant enzyme involved in gibberellin synthesis. DNA Research, 2002, vol. 9, no. 1, p. 11-17.

OIKAWA, T.; KOSHIOKA, M.; KOJIMA, K.; YOSHIDA, H. and KAWATA, M. A role of OsGA20ox1, encoding an isoform of gibberellin 20-oxidase, for regulation of plant stature in rice. Plant Molecular Biology, November 2004, vol. 55, no. 5, p. 687-700.

REDDY, G.M. and PADMA, A. Some induced dwarfing genes non-allelic to Dee-geo-woo-gen gene in rice, variety Tellakattera. Theoretical and Applied Genetics, May 1976, vol. 47, no. 3, p. 115-118.

RUTGER, J. Induced semidwarf mutants. Rice Genetics Newsletter, November 1984, vol. 1, p. 92 - 93.

SAKAMOTO, T.; MORINAKA, Y.; ISHIYAMA, K.; KOBAYASHI, M.; ITOH, H.; KAYANO, T.; IWAHORI, S.; MATSUOKA, M. and TANAKA, H. Genetic manipulation of gibberellin metabolism in transgenic rice. Nature Biotechnology, August 2003, vol. 21, no. 8, p. 909913.

SAKAMOTO, T.; MIURA, K.; ITOH, H.; TATSUMI, T.; UEGUCHI-TANAKA, M.; ISHIYAMA, K.; KOBAYASHI, M.; AGRAWAL, G.K.; TAKEDA, S.; ABE, K.; MIYAO, A.; HIROCHIKA, H.; KITANO, H.; ASHIKARI, M. and MATSUOKA, M. An overview of gibberellin metabolism enzyme genes and their related mutants in rice. Plant Physiology, April 2004, vol. 134, no. 4, p. 1642-1653. 
SASAKI, A.; ASHIKARI, M.; UEGUCHI-TANAKA, M.; ITOH, H.; NISHIMURA, A.; SWAPAN, D.; ISHIYAMA, K.; SAITO, T.; KOBAYASHI, M.; KHUSH, G.S.; KITANO, H. and MATSUOKA, M. Green revolution: a mutant gibberellin-synthesis gene in rice. Nature, April 2002, vol. 416, no. 6882, p. 701-702.

SATO, Y; SENTOKU, N.; MIURA, Y.; HIROCHIKA, H.; KITANO, $\mathrm{H}$. and MATSUOKA, M. Loss-of-function mutations in the rice homeobox gene OSH15 affect the architecture of internodes resulting in dwarf plants. $E M B O$ Journal, February 1999, vol. 18, no. 4, p. 992-1002.

SINGH, V.P.; SIDDIQ, E.A. and SWAMINATHAN, M.S. Mode of inheritance of dwarf stature and allelic relationships among various spontaneous and induced dwarfs of cultivated rice Oryza sativa L. Theoretical and Applied Genetics, May 1979, vol. 55, no. 3-4, p. 169-176.

SPIELMEYER, W.; ELLIS, M.H. and CHANDLER, P.M. Semidwarf sd-1, "green revolution" rice, contains a defective gibberellin 20-oxidase gene. Proceedings of the National Academy of Sciences of the United States of America, June 2002, vol. 99, no. 13, p. 9043-9048.

TAKEDA, K. Internode elongation and dwarfism in some gramineous plants. Gamma Field Symposia, July 1977, vol. 16, p. 1-18.

UEGUCHI-TANAKA, M.; FUJISAWA, Y.; KOBAYASHI, M.; ASHIKARI, M.; IWASAKI, Y.; KITANO, H. and MATSUOKA, M. Rice dwarf mutant d1, which is defective in the alpha subunit of the heterotrimeric $G$ protein, affects gibberellin signal transduction. Proceedings of the National Academy of Sciences of the United States of America, October 2000, vol. 97, no. 10, p. 11638-11643.

YAMAMURO, C.; IHARA, Y.; WU, X.; NOGUCHI, T.; FUJIOKA, S.; TAKATSUTO, S.; ASHIKARI, M.; KITANO, H. and MATSUOKA, M. Loss of function of a rice brassinosteroid insensitive1 homolog prevents internode elongation and bending of the lamina joint. Plant Cell, September 2000, vol. 12, no. 9, p. 1591-1606. 


\section{APPENDIX}

Supplementary Table 1. DGWG allele and its flanking region in the rice genome

\begin{tabular}{|c|c|c|c|c|c|c|c|c|c|c|c|c|c|c|}
\hline $\begin{array}{l}\text { S. } \\
\text { No }\end{array}$ & Accession & RM11952 & RM11971 & RM11975 & RM11959 & RM11961 & RM11963 & RM11967 & $\begin{array}{c}\text { DGWG allele } \\
\text { of so't }\end{array}$ & RM11979 & RM11997 & $\begin{array}{c}\text { GA } \\
\text { respor } \\
\text { se }\end{array}$ & Accession & $\begin{array}{l}\text { Length } \\
\text { of the } \\
\text { deletion } \\
\text { (kb) }\end{array}$ \\
\hline 1 & MLL151 & 480 & $\cdot$ & $\cdot$ & 310 & 190 & 100 & 190 & $\cdot$ & $\cdot$ & 650 & $M$ & W'L131 & 783.11 \\
\hline 2 & WLLO & 450 & 175 & 200 & 310 & $\cdot$ & 80 & 190 & 348 & 330 & $\cdot$ & $M$ & WUL146 & 783.11 \\
\hline 3 & WULL85 & $\cdot$ & $\cdot$ & $\cdot$ & $\cdot$ & $\cdot$ & $\cdot$ & $\cdot$ & $\cdot$ & $\cdot$ & 850 & $M$ & 4070 & 783,11 \\
\hline 4 & WLOOO & 480 & 175 & 200 & 310 & 170 & 90 & 190 & $\cdot$ & 380 & 600 & $\mathrm{H}$ & WULL85 & 531,50 \\
\hline 5 & WL131 & $\cdot$ & $\cdot$ & $\cdot$ & $\cdot$ & $\cdot$ & $\cdot$ & $\cdot$ & $\cdot$ & $\cdot$ & $\cdot$ & $M$ & C.Panicle & 490,46 \\
\hline 6 & WLL146 & $\cdot$ & $\cdot$ & $\cdot$ & $\cdot$ & $\cdot$ & $\cdot$ & $\cdot$ & $\cdot$ & $\cdot$ & $\cdot$ & L & $\mathrm{C} 66$ & 400,43 \\
\hline 7 & W'L158 & 480 & 175 & $\cdot$ & $\cdot$ & 180 & 90 & 190 & 348 & $\cdot$ & 600 & $\mathrm{H}$ & $\mathrm{C59}$ & 195,69 \\
\hline 8 & Wúl200 & 450 & $\cdot$ & $\cdot$ & 310 & 190 & - & $\cdot$ & $\cdot$ & 370 & 600 & $\mathrm{~L}$ & $468 \mathrm{D}$ & 195.69 \\
\hline 9 & mí244 & 450 & 175 & 200 & 310 & 190 & 80 & 190 & 731 & $\cdot$ & $\cdot$ & $L$ & WL200 & 182,09 \\
\hline 10 & $\mathrm{C} 66$ & $\cdot$ & $\cdot$ & 200 & $\cdot$ & 150 & 80 & $\cdot$ & $\cdot$ & $\cdot$ & $\cdot$ & $M$ & $\mathrm{C72}$ & 182,09 \\
\hline 11 & C67 & 474 & 175 & $\cdot$ & 310 & 170 & 90 & 190 & 348 & 380 & 650 & $M$ & $\mathrm{C} 90$ & 182,09 \\
\hline 12 & $\mathrm{C} 68$ & 474 & 175 & 200 & $\cdot$ & $\cdot$ & 100 & 190 & $\cdot$ & 370 & 600 & $M$ & $\mathrm{C75}$ & 182,09 \\
\hline 13 & $\mathrm{C} 69$ & 450 & 190 & 200 & 310 & 190 & 100 & 210 & 348 & 330 & 650 & $M$ & Ar seed & 182,09 \\
\hline 14 & C72 & 450 & $\cdot$ & 200 & 310 & 190 & $\cdot$ & $\cdot$ & $\cdot$ & 325 & 600 & $\mathrm{~L}$ & $728 \mathrm{D}$ & 92,68 \\
\hline 15 & C74 & 450 & 175 & 200 & 310 & 200 & $\cdot$ & $\cdot$ & 348 & 350 & 600 & $L$ & Bफ68 & 92,68 \\
\hline 16 & $\mathrm{C} 59$ & 480 & $\cdot$ & 200 & 310 & $\cdot$ & $\cdot$ & $\cdot$ & $\cdot$ & 370 & 600 & L & C70 & 92,68 \\
\hline 17 & C81 & 450 & 175 & 200 & 310 & 170 & 100 & 210 & 348 & 370 & 650 & $M$ & 4410 & 92,68 \\
\hline 18 & $\mathrm{C} 90$ & 450 & 175 & 200 & 310 & 190 & - & $\cdot$ & $\cdot$ & 330 & 650 & $\mathrm{~L}$ & W'L151 & 59,82 \\
\hline 19 & Bijorll & 474 & 190 & 200 & 310 & 180 & 100 & 190 & 348 & 325 & 650 & $\mathrm{H}$ & W'L158 & 59,82 \\
\hline 20 & Ajjuri & 480 & 175 & 200 & 310 & 180 & 100 & 190 & 348 & 350 & $\cdot$ & $M$ & WLLO & 3.12 \\
\hline 21 & $728 \mathrm{D}$ & - & & 200 & 310 & 200 & 80 & 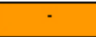 & $\cdot$ & 350 & 600 & $M$ & $\mathrm{C} 68$ & 3.12 \\
\hline 22 & BM48 & 480 & $\cdot$ & $\cdot$ & 310 & 170 & 80 & $\cdot$ & $\cdot$ & 370 & 600 & $M$ & $409 \mathrm{D}$ & 3.12 \\
\hline 23 & $C 70$ & 450 & $\cdot$ & 200 & 310 & 170 & 80 & $\cdot$ & $\cdot$ & 350 & $\cdot$ & $L$ & & \\
\hline 24 & $\mathrm{C75}$ & 480 & $\cdot$ & 200 & 310 & 170 & $\cdot$ & $\cdot$ & $\cdot$ & 350 & 600 & $M$ & & \\
\hline 25 & Chlorina & 450 & 175 & 200 & 310 & 170 & 90 & 190 & 348 & 350 & 650 & $\mathrm{~L}$ & $\mathrm{H}$ & high \\
\hline 26 & C.Panicle & 450 & & 200 & 310 & 180 & - & $\cdot$ & $\cdot$ & $\cdot$ & $\cdot$ & $M$ & $M$ & medium \\
\hline 27 & Ar. seed & $\cdot$ & $\cdot$ & $\cdot$ & 310 & 190 & - & $\cdot$ & $\cdot$ & 325 & 600 & $\mathrm{~L}$ & L & low \\
\hline 28 & $408 \mathrm{D}$ & 450 & 175 & 200 & $\cdot$ & 190 & 80 & 190 & 348 & 370 & $\cdot$ & $\mathrm{H}$ & & \\
\hline 29 & 4410 & $\cdot$ & $\cdot$ & 200 & 310 & 190 & 80 & - & - & 380 & 850 & $M$ & & \\
\hline 30 & $409 \mathrm{D}$ & 450 & 190 & 200 & 310 & 200 & 80 & 190 & $\cdot$ & 350 & 650 & $M$ & & \\
\hline 31 & 4070 & $\cdot$ & $\cdot$ & $\cdot$ & $\cdot$ & $\cdot$ & - & $\cdot$ & $\cdot$ & - & - & $M$ & & \\
\hline 32 & $468 \mathrm{D}$ & 480 & $\cdot$ & $\overline{-}$ & 310 & $\cdot$ & $\overline{-}$ & $\overline{-}$ & $\overline{-}$ & 325 & 600 & $M$ & & \\
\hline 33 & IR8 & 450 & 190 & 200 & 310 & 180 & 80 & 190 & 348 & 380 & 600 & $M$ & & \\
\hline 34 & TN1 & 450 & 175 & 200 & 310 & 170 & 100 & 190 & 348 & 370 & 650 & $M$ & & \\
\hline \multirow[t]{8}{*}{35} & Nipponbare & 500 & 190 & 200 & 310 & 190 & 110 & 200 & 731 & 400 & 670 & $L$ & & \\
\hline & $\begin{array}{c}\text { Region on } \\
\text { Chr.1 }\end{array}$ & 38237550 & 38317133 & 38339685 & 38381693 & 38516668 & 38530267 & 38619715 & 38709231 & 38765924 & 39017538 & & & \\
\hline & & 38237950 & 38317153 & 38339704 & 38382003 & 38516855 & 38530479 & 38619918 & 38.712 .353 & 38766322 & 39018208 & & & \\
\hline & Intenval & 79,583 & 22,552 & 42,008 & 134,975 & 13,599 & 89,448 & 89,516 & 56,693 & 251,614 & & & & \\
\hline & & 471,681 & 392,098 & 369,546 & 327,538 & 192,563 & 178,964 & 89,516 & & 56,693 & 308,307 & & & \\
\hline & & & & & & & & 67,383 & $3.122 \mathrm{~kb}$ & 182,5 & & & & \\
\hline & & & & & & & & & & & & & & \\
\hline & & & & & & & & 124,9415 & & & & & & \\
\hline
\end{tabular}




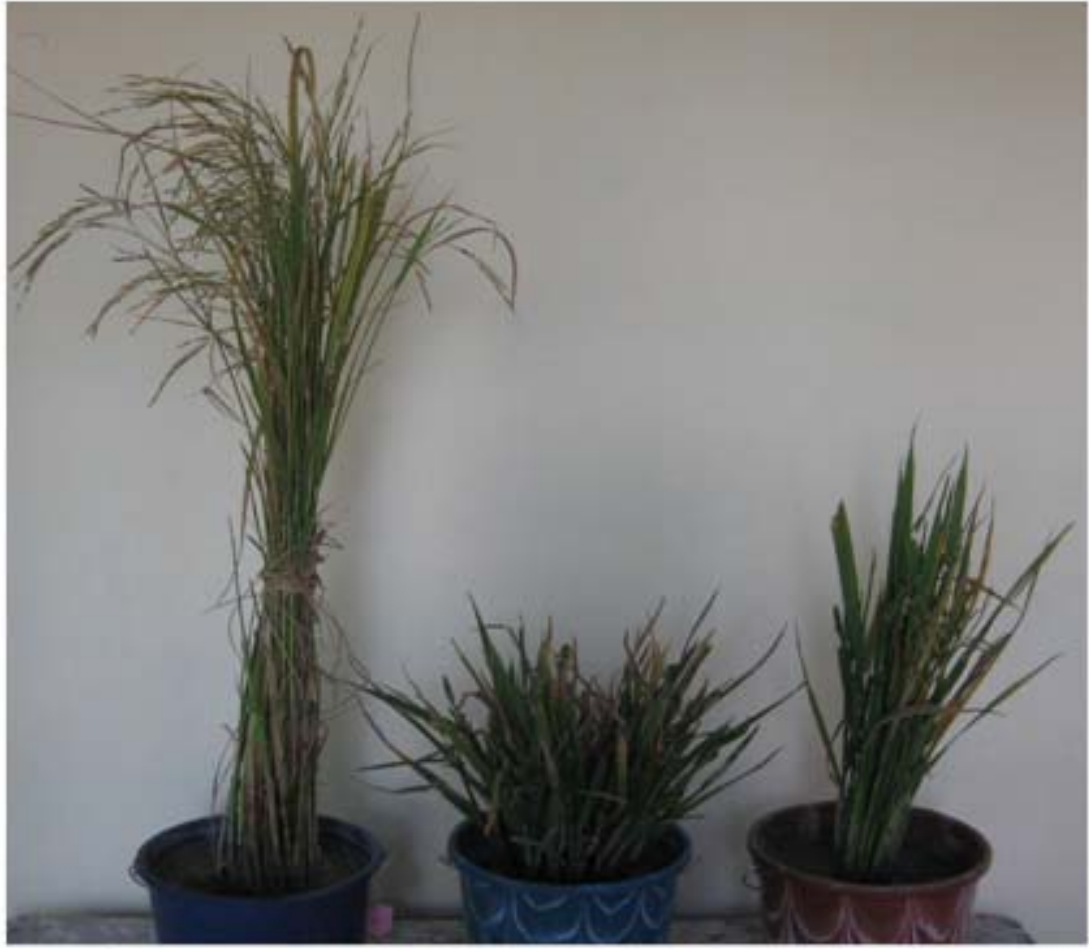

TN1

C-81

WL200

Supplementary Figure 1. Plant types of Dwarf accessions 